\title{
Modelling an Integrated Fuzzy Logic and Multi-Criteria Approach for Land Capability Assessment for Optimized Municipal Solid Waste Landfill Siting Yeast
}

\author{
Mona Soroudi ${ }^{1}$, Ghasemali Omrani' ${ }^{1 *}$, Faramarz Moataar' ${ }^{1}$, Seyed Ali Jozi ${ }^{2}$ \\ 'Department of Environmental Science, Science and Research Branch, Islamic Azad University, Tehran, Iran \\ ${ }^{2}$ Department of Environmental Science, North Tehran Branch, Islamic Azad University, Tehran, Iran
}

Received: 14 January 2017

Accepted: 16 March 2017

\begin{abstract}
The rapid growth of municipal solid waste (MSW) is considered one of the greatest environmental challenges in both developed and developing countries. Among the numerous approaches in solid waste management, the sanitary landfill is still the most common in many countries, including Iran. The multiplicity of factors affecting MSW landfill siting on the one hand, and the importance of applying an efficient method on the other, has led to conducting multi-criteria decision-making integrated with geographic information system (GIS) to evaluate Hassan-Abad land capability. Therefore, 20 criteria were categorized into ecological and socio-economic classes, and the analytical network process model was used to compute the weights. Statistics show that the most considerable items in landfill siting are distance from roads and built-up areas and soil with weights of $0.080466,0.074147$, and 0.062027 , respectively. Moreover, the final capability map generated by the weighted linear combination method represents that $82 \%$ of the study area has no capability for landfill siting, while low, moderate, and high capability classes cover $12 \%, 5 \%$, and $1 \%$ of Hasan-Abad, respectively. The results indicate the efficiency of the integrated method in land capability assessment for MSW landfill siting.
\end{abstract}

Keywords: landfill site selection, GIS, ANP, WLC, fuzzy logic, MCDM, municipal solid waste

\section{Introduction}

Today, uncontrolled urban development and increasing population growth along with lifestyle changes and lack of proper consumption patterns have led to a dramatic increase in the production of urban municipal waste.

*e-mail: omrani.ghasemali1325@gmail.com
Thus, not only modern societies but also developing ones are faced with two major environmental challenges, including overuse of non-renewable resources and the problem of municipal solid waste (MSW) disposal [1-3]. Therefore, urban solid waste management is not only a critical environmental issue, but it also involves a wide range of social, cultural, and economic factors that need to be considered as a priority [3-6]. These factors must be considered to achieve a sustainable urban environment as one of the significant aspects of sustainable development. 
Produced waste reduction, reuse, recycling, energy recovery, incineration, and sanitary landfills are wellknown municipal waste management strategies that can help achieve sustainable development goals [7-9].

This is despite the fact that even if a combination of the above methods are used to manage MSWs, again, the need for a sanitary landfill is undeniable [10-11] so that this strategy is even considered one of the most wellknown municipal waste management options [12-18]. However, it should be noted that suitable landfill siting is a complex process due to social, economic, environmental, and technical factors [19-20]. The environmental factors are important because the landfill may adversely impact the biophysical and ecological environment around the landfill area [21].

Economic factors are applied in the process of landfill siting due to the importance of the economic cost of buying land, plus development and construction operations such as sanitation and leveling [22-23]. The role of social factors is also important because they are often referred to as one of the greatest obstacles to proper landfill sites [16]. Thus, given the multiplicity of factors affecting the selection of proper landfill sites, it is essential to apply spatial information technologies and integrate them with management practices, including the integrated use of geographic information system (GIS) and multi-criteria decision-making methods (MCDM) as an approach with the highest potential in landfill sites [18, 24-26].

A review of literature indicates that the mentioned integrated techniques with several MCDM approaches such as AHP, analytical network process (ANP), and weighted linear combination (WLC) has been applied in many studies [10-12, 25-36]. Similarly, four main criteria, including geomorphology, hydrology, humanistic, and land use, and eight sub-criteria were considered in [31] to locate a suitable landfill for Jiroft, Iran, using the integration of AHP and GIS. The authors in [9] and [33] applied WLC and AHP focused on hydrology, wind orientation, slope, distance from the road, and residential areas as significant parameters to carry out landfill site selection in the two Iranian metropolitan areas of Gorgan and Karaj, respectively. In [17] AHP and GIS were combined for landfill site selection in Konya, Turkey. The distance from transportation routes and rail, the distance from archaeological sites, urban areas, land use/land cover, and slope were taken as factors in the investigation. Moreover, [37] noted significant factors like slope, stream network, well, fault, urban area, road, aquifer, and agricultural areas in the landfill siting process in Mafraq, Jordan. Finally, through the integration of GIS, WLC, and AHP, three spots as the optimum result for landfill sites were suggested. In another investigation, fuzzy logic and ANP were conducted to perform a landfill site selection procedure for Qom, Iran. The four indices of accessibility, hydrology, natural-topography, and public acceptance were introduced as the main criteria in this research [38]. In addition, authors in [39] performed the study of landfill site selection using GIS and the analytical hierarchy process in Al-Hillah Qadhaa, Babylon, Iraq and considered 15 natural-environmental and artificial criteria.

The existing research aimed to:

1. Introduce a comprehensive approach in land capability assessment for MSW landfill siting as a challenging environmental and socio-economic task.

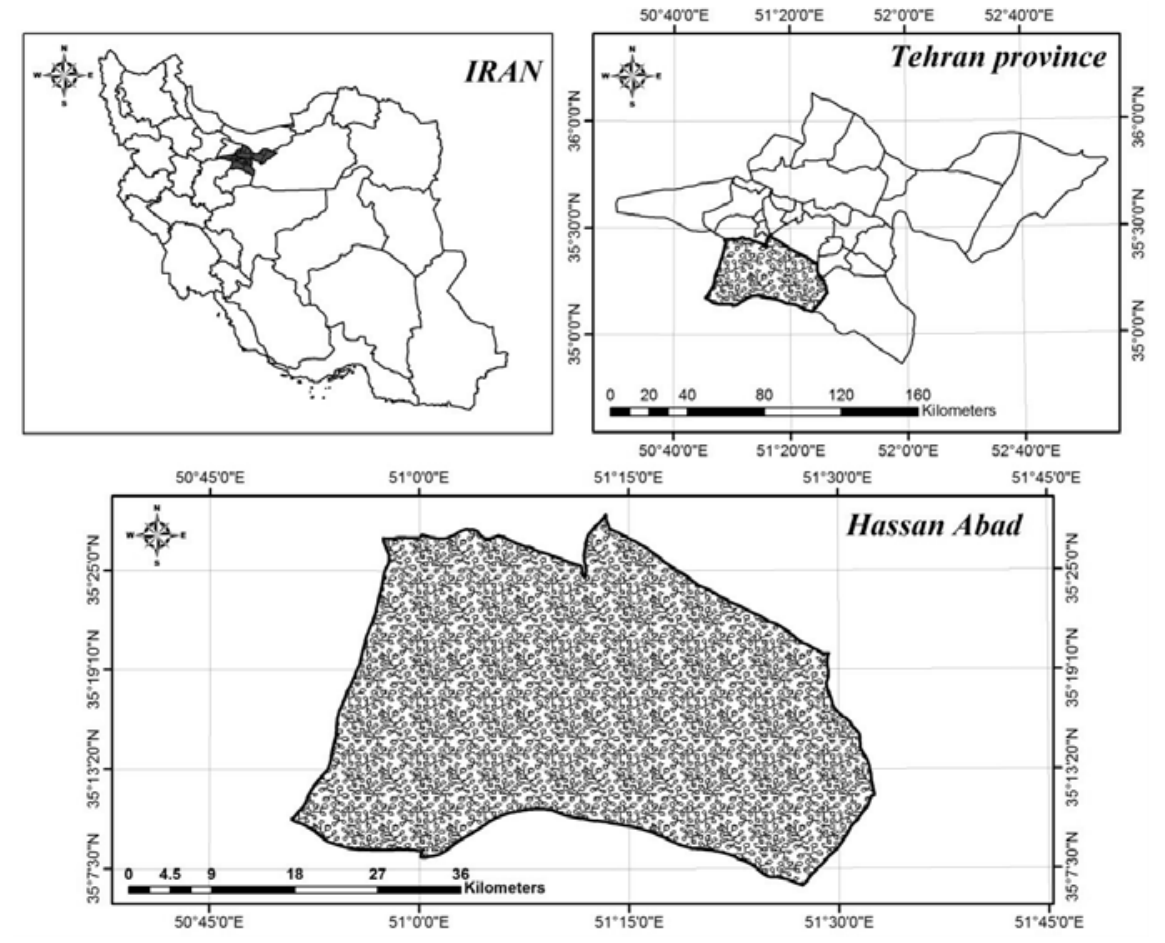

Fig. 1. The study area in Tehran Province, Iran. 
2. Employ MCDM, emphasizing the ANP algorithm and fuzzy logic.

\section{Materials and Methods}

\section{Study Area}

Hasan Abad, with an area of 16,102.97 hectares and dry and very dry climatic conditions, is the center of the Fashapuyeh District of Tehran Province and is located in the southern part of the province (Fig. 1). Demographic studies show that the population of the study area increased between 2006 and 2015, from 21,435 to 45,100 people, respectively. This is in spite of the fact that the municipality acknowledges that the daily production of waste in the region has increased 1.75 times in this area over the years, and there is a dire need to determine suitable location for sanitary landfills in the region [40].

The methodological procedure of the study includes 12 phases that are represented step-by-step in Fig. 2.

\section{Criteria Selection}

In the existing study, according to the literature review, we investigated various parameters regarding the selection of suitable landfill sites. Afterward, by designing them in the form of questionnaires, the opinions of waste management experts and environmental specialists who were familiar with the study area were pulled, and the final parameters for locating landfills were selected according to the Delphi method. These parameters were selected in the form of ecological factors such as soil (depth, soil permeability, erosion), water resources (river, spring, lakes), physiographic factors (slope, height, and aspect based on wind direction), geological factors, fault, environmentally protected areas, environmental and economic social criteria, land use (agricultural land,

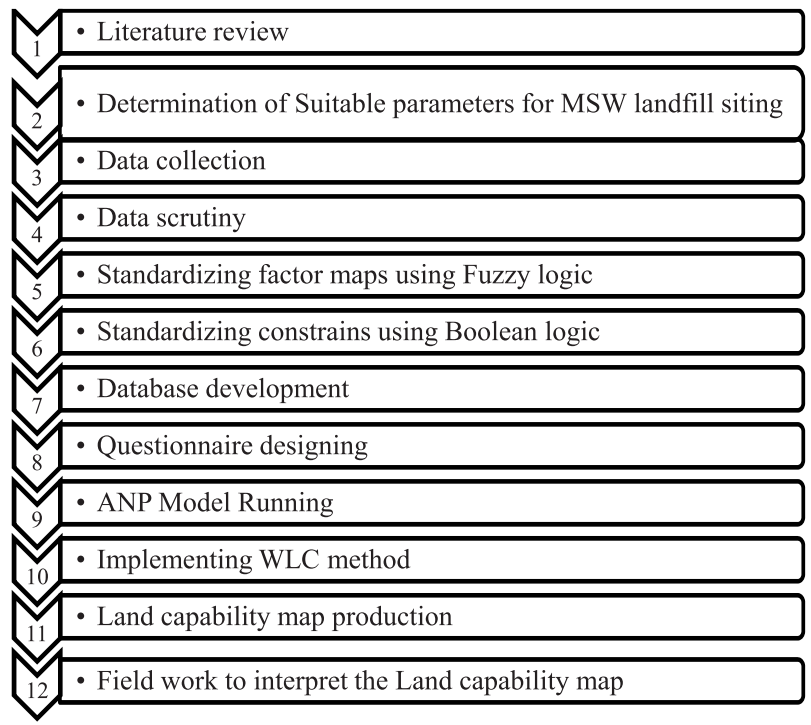

Fig. 2. Methodological flowchart. orchards), distances from roads, distance from built-up lands (industrial, residential, healthcare centers, and city area in total), and distances from historic sites, mines, airports, railways, and infrastructure. In order to develop the database, digitized maps (thematic information) were prepared and scrutinized in GIS.

\section{ANP Method}

Regarding the questionnaires, the ANP method under the Super Decision Software environment was used to determine the weight of criteria and indices based on expert opinions. This technique is a holistic approach and is known as one of the most widely used methods of MCDM [41-42, 44]. In this method, studied criteria and indices are given in the form of questionnaires to the relevant experts for pairwise comparisons and rating in a standard way as shown in Table 1. It should be noted that Cochrane's Formula and Morgan's Table were used in this study to determine the required number of questionnaires [41, 44-45]. Accordingly, a total of 20 questionnaires were designed using the Delphi method to distribute later among the experts who were familiar with Hasan-Abad conditions in order to rate criteria and indices.

Research indicates that the ANP technique can strongly consider the necessary formation for uncertain pairwise comparisons [43, 48-49], and it is also able to provide much better explanations in multi-decisionmaking procedures [47, 50]. Generally, in ANP procedure first and foremost, a specific vector, w, should be calculated by the equation:

$$
\mathrm{AW}=\lambda_{\max } \mathrm{W}
$$

$\ldots$ where $\lambda_{\text {max }}$ is the greatest specific numerical value of the pairwise comparison matrix A, and w shows the relative importance of criteria and indices [46, 51-52]. Moreover, it is necessary to introduce a normalization algorithm to solve $\mathrm{w}$ approximately. The pairwise comparison matrix is gained as relationship (2), while the significance distribution of criteria and indices as a percentage is acquired as relationships (4), (5), and (6) [51, 53].

Table 1. ANP pair wise comparison scale [46-47].

\begin{tabular}{|c|c|}
\hline Definition & $\begin{array}{c}\text { Intensity of } \\
\text { importance }\end{array}$ \\
\hline Equally important & 1 \\
\hline Weakly important & 3 \\
\hline Strongly important & 5 \\
\hline Demonstratively important & 7 \\
\hline Absolutely important & 9 \\
\hline $\begin{array}{c}\text { Intermediate value between adjacent scale } \\
\text { values }\end{array}$ & $2,4,6,8$ \\
\hline
\end{tabular}




$$
\begin{gathered}
\mathrm{A}=\left[\mathrm{a}_{\mathrm{ij}}\right]_{\mathrm{nxn}} \quad \mathrm{i}=1, \ldots \ldots, \mathrm{n} \\
\mathrm{B}_{\mathrm{i}}=\left[\mathrm{b}_{\mathrm{ij}}\right]_{\mathrm{nx} 1} \quad \mathrm{i}=1, \ldots \ldots, \mathrm{n} \\
\mathrm{b} \mathrm{b}_{\mathrm{ij}}=\mathrm{a}_{\mathrm{ij}} / \sum_{\mathrm{i}=1}^{\mathrm{n}} \mathrm{a}_{\mathrm{ij}} \\
\mathrm{i}=1, \ldots, \mathrm{n} \quad \mathrm{j}=1, \ldots, \mathrm{n} \\
\left.\mathrm{w}_{\mathrm{i}}\right]_{\mathrm{nxn}}=\sum_{\mathrm{j}=1}^{\mathrm{n}} \mathrm{c}_{\mathrm{ij}} / \mathrm{n} \quad \mathrm{W}=\left[\mathrm{w}_{\mathrm{i}}\right]_{\mathrm{nx} 1}
\end{gathered}
$$

Afterward, it is absolutely essential to check the pairwise matrix consistency through computing an index named consistency index (CI), which is calculated by the mathematical formulas below:

$$
\begin{gathered}
\mathrm{D}=\left[\mathrm{a}_{\mathrm{ij}}\right]_{\mathrm{nxn}} \mathrm{X}\left[\mathrm{w}_{\mathrm{i}}\right]_{\mathrm{nx} 1}=\left[\mathrm{d}_{\mathrm{i}}\right]_{\mathrm{nx} 1} \\
\mathrm{E}_{\mathrm{i}}=\frac{\mathrm{d}_{\mathrm{i}}}{\mathrm{w}_{\mathrm{i}}} \quad \mathrm{i}=1, \ldots \ldots, \mathrm{n} \\
\lambda=\sum_{\mathrm{i}=1}^{\mathrm{n}} \mathrm{E}_{\mathrm{i}} / \mathrm{n} \\
\mathrm{CR}=\frac{\mathrm{CI}}{\mathrm{RI}}
\end{gathered}
$$

In equation (10), CI, RI, and CR stand for consistency indicator, random indicator, and consistency ratio, respectively. Researchers note that the acceptable CI is less than 0.10 [51, 53].

In addition, the point is, if the matrixes are not completely developed or so-called, they are primitive, the limiting value in the form of the limited super matrix is gained by putting the specific vector, w, to powers, as presented in equation (11) [51, 54].

$$
\mathrm{W}^{\infty}=\lim _{\mathrm{k} \rightarrow \infty} \mathrm{W}^{\mathrm{k}}
$$

Furthermore, the super matrix indicating a hierarchy with three specific levels of goal, criteria, and alternatives is as follows:

$$
\mathrm{W}=\underset{\text { criteria }}{\text { goal }}\left[\begin{array}{ccc}
0 & 0 & 0 \\
\mathrm{w}_{21} & 0 & 0 \\
0 & \mathrm{w}_{32} & \mathrm{I}
\end{array}\right]_{(12)}
$$

In this matrix, $w_{21}$ and $w_{32}$ are two vectors that indicate the goal's impact on the criteria and the criteria's impact on each and every alternative, respectively. Here, I and $\mathrm{W}$ are referred to as the identity and super matrix, respectively $[51,55]$.

\section{Standardizing Map Layers}

At this stage, all of the criteria and indices were normalized by conducting the fuzzy logic method. Due to using a various range of scales in measurement of the criteria, it is undoubtedly essential to standardize each and every criterion before any further combination [12, 41, 56-57]. Therefore, factor maps have been standardized based on the fuzzy logic rules on the scale of bytes (0-1) with regard to the related fuzzy membership functions. In the mentioned range of $0-1$, a higher value shows greater suitability and a lower one indicates less $[41,56,58]$. To "fuzzify" the factor maps, it is important to determine the threshold values of the criteria accompanied by the type of fuzzy membership functions [41, 59]. The fuzzy membership functions used in this research are named linear (monotonically decreasing and monotonically increasing) and discrete (Table 2).

Here, the linear scale conversion method (LSCM) with the mentioned equation (13) are employed to convert criteria maps to fuzzy layers $[41,60]$ :

$$
\mathrm{X}_{\mathrm{i}}=\frac{\mathrm{R}_{\mathrm{i}}-\mathrm{R}_{\min }}{\mathrm{R}_{\max }-\mathrm{R}_{\text {min }}} * \text { Standardized Range }
$$

...where standardized range represents the range of changes in standardization and $X_{i}, R_{i}, R_{\min }$, and $R_{\max }$ denote the cell's value following standardization, the cell's value before standardization, the minimum value in the factor, and the maximum value in the factor, respectively [60]. By reviewing [41], to fuzzify some factor maps (criteria) such as erosion, soil depth, geology, height, etc., which follow a discrete pattern of fuzzy membership and lack continuity between descriptive numbers or states, first of all the fuzzy values related to each class are computed using formula (13). Afterward, one field, named "fuzzy field," is defined in the attribute table of that factor map in GIS software, and then fuzzy numbers are transferred to the mentioned field.

Note that in the landfill site selection procedure there are two sets of maps, named factor maps and constraints. Constraints specify the areas that cannot be used for a specific purpose at all (e.g., the inner sides (polygon) of land use, airport, lake, springs, built-up areas, historical places). In order to standardize constraints, Boolean logic based on the value of 0,1 is used, where constrains take zero and other parts take 1 [41].

\section{Weighted Linear Combination Method}

At this step, to create a landfill suitability map we carried out the WLC method. In fact, WLC is a method of evaluation that represents cell suitability by weighing and combining factor map layers [56, 61]. Equation (14) shows the mathematical formulation of this method [11, 23, 41].

$$
S_{f}=\sum_{i=1}^{N} W_{i} X_{i}
$$

...where $S_{f}$ stands for total suitability index value (0-1) of factor maps, $W_{i}$ and $X_{i}$ indicate weight and criterion score 
Table 2. Fuzzy membership function of the criteria (factor maps) in WLC method to assess capability for landfill siting.

\begin{tabular}{|c|c|c|c|}
\hline Criteria & $\begin{array}{l}\text { Function of fuzzy } \\
\text { membership }\end{array}$ & $\begin{array}{l}\text { Primitive } \\
\text { limits }\end{array}$ & Fuzzy format \\
\hline Erosion & Discrete & & High erosion equal to 0.6 , moderate erosion equal to 0.4 \\
\hline Soil depth $(\mathrm{cm})$ & Discrete & & $\begin{array}{l}\text { Very deep equal to } 1 \text {, deep equal to } 0.8 \text {, moderately deep equal to } \\
0.6 \text {, semi-shallow equal to } 0.4 \text {, shallow equal to } 0.2\end{array}$ \\
\hline Soil permeability & Discrete & & $\begin{array}{l}\text { Very slow equal to } 1 \text {, slow equal to } 0.8 \text {, medium equal to } 0.6 \text {, rapid } \\
\text { equal to } 0.2\end{array}$ \\
\hline Slope $(\%)$ & Discrete & & $0-10 \%$ equal to $1,10-20 \%$ between $0-1$, more than $20 \%$ equal to 0 \\
\hline $\begin{array}{l}\text { Aspect } \\
\text { (based on wind } \\
\text { direction) }\end{array}$ & Discrete & & $\begin{array}{l}\text { E equal to } 1, \mathrm{NE}, \mathrm{SE} \text { equal to } 0.8, \mathrm{~N}, \mathrm{~S} \text { equal to } 0.4, \mathrm{~W}, \mathrm{SW}, \mathrm{NW} \\
\text { equal to } 0.2\end{array}$ \\
\hline Height (m) & Discrete & & $\begin{array}{c}1,000-1,250 \mathrm{~m} \text { equal to } 1,1,250-2,000 \mathrm{~m} \text { between } 0-1, \text { more than } \\
2,000 \mathrm{~m} \text { equal to } 0\end{array}$ \\
\hline Geology & Discrete & & $\begin{array}{l}\text { Sandstone, siltstone, marl and bituminous shale equal to } 0.8 \text {; sandy } \\
\text { clay and conglomerate equal to } 0.6 \text {; limestone and sandstone equal } \\
\text { to } 0.2 \text {; sand equal to } 0\end{array}$ \\
\hline $\begin{array}{l}\text { Distance from } \\
\text { historical sites }\end{array}$ & $\begin{array}{c}\text { Monotonically } \\
\text { increasing (linear) }\end{array}$ & & $\begin{array}{l}0-1,500 \mathrm{~m} \text { equal to } 0,1,500-4500 \mathrm{~m} \text { between } 0-1 \text {, more than } 4,500 \\
\text { m equal to } 1\end{array}$ \\
\hline $\begin{array}{l}\text { Distance from } \\
\text { environmentally } \\
\text { protected areas }\end{array}$ & $\begin{array}{l}\text { Monotonically } \\
\text { increasing (linear) }\end{array}$ & & $\begin{array}{c}0-2,000 \mathrm{~m} \text { equal to } 0,2,000-6,000 \mathrm{~m} \text { between } 0-1 \text {, more than } 6,000 \\
\mathrm{~m} \text { equal to } 1\end{array}$ \\
\hline $\begin{array}{l}\text { Distance from } \\
\text { land use }\end{array}$ & $\begin{array}{c}\text { Monotonically } \\
\text { increasing (linear) }\end{array}$ & & $\begin{array}{l}0-2,000 \mathrm{~m} \text { equal to } 0,2,000-6,000 \mathrm{~m} \text { between } 0-1 \text {, more than } 6,000 \\
\text { m equal to } 1\end{array}$ \\
\hline Distance from road $(\mathrm{m})$ & $\begin{array}{c}\text { Monotonically } \\
\text { decreasing (linear) }\end{array}$ & $\begin{array}{l}0-500(\mathrm{~m}) \\
\text { Buffer }\end{array}$ & $\begin{array}{l}500-2,000 \mathrm{~m} \text { equal to } 1,2,000-4,000 \mathrm{~m} \text { between } 1-0 \text {, more than } \\
\qquad 4,000 \mathrm{~m} \text { equal to } 0\end{array}$ \\
\hline $\begin{array}{l}\text { Distance from Built-up } \\
\text { Area }(\mathrm{m})\end{array}$ & $\begin{array}{c}\text { Monotonically } \\
\text { decreasing (linear) }\end{array}$ & $\begin{array}{l}0-3000(\mathrm{~m}) \\
\text { Buffer }\end{array}$ & $\begin{array}{l}3,000-4,500 \mathrm{~m} \text { equal to } 1,4,500-6,000 \mathrm{~m} \text { between } 1-0, \text { more than } \\
\qquad 6,000 \mathrm{~m} \text { equal to } 0\end{array}$ \\
\hline Distance from river $(\mathrm{m})$ & $\begin{array}{l}\text { Monotonically } \\
\text { increasing (linear) }\end{array}$ & & $\begin{array}{l}0-2,000 \mathrm{~m} \text { equal to } 0,2,000-4,000 \mathrm{~m} \text { between } 0-1 \text {, more than } 4,000 \\
\text { m equal to } 1\end{array}$ \\
\hline $\begin{array}{l}\text { Distance from spring } \\
(\mathrm{m})\end{array}$ & $\begin{array}{c}\text { Monotonically } \\
\text { increasing (linear) }\end{array}$ & & $\begin{array}{l}0-2,000 \mathrm{~m} \text { equal to } 0,2,000-4,000 \mathrm{~m} \text { between } 0-1 \text {, more than } 4,000 \\
\text { m equal to } 1\end{array}$ \\
\hline Distance from lake (m) & $\begin{array}{c}\text { Monotonically } \\
\text { increasing (linear) }\end{array}$ & & $\begin{array}{c}0-2,000 \mathrm{~m} \text { equal to } 0,2,000-4,000 \mathrm{~m} \text { between } 0-1 \text {, more than } 4,000 \\
\text { m equal to } 1\end{array}$ \\
\hline $\begin{array}{l}\text { Distance from airport } \\
\qquad(\mathrm{m})\end{array}$ & $\begin{array}{c}\text { Monotonically } \\
\text { increasing (linear) }\end{array}$ & & $\begin{array}{l}0-8,000 \mathrm{~m} \text { equal to } 0,8,000-10,000 \mathrm{~m} \text { between } 0-1 \text {, more than } \\
\qquad 10,000 \mathrm{~m} \text { equal to } 1\end{array}$ \\
\hline Distance from mine & $\begin{array}{c}\text { Monotonically } \\
\text { increasing (linear) }\end{array}$ & & $\begin{array}{c}0-2,000 \mathrm{~m} \text { equal to } 0,2,000-4,000 \mathrm{~m} \text { between } 0-1 \text {, more than } 4,000 \\
\text { m equal to } 1\end{array}$ \\
\hline $\begin{array}{l}\text { Distance from } \\
\text { infrastructure }\end{array}$ & $\begin{array}{c}\text { Monotonically } \\
\text { increasing (linear) }\end{array}$ & & $\begin{array}{l}0-500 \mathrm{~m} \text { equal to } 0,500-1,500 \mathrm{~m} \text { between } 0-1 \text {, more than } 1,500 \mathrm{~m} \\
\text { equal to } 1\end{array}$ \\
\hline Distance from fault & $\begin{array}{c}\text { Monotonically } \\
\text { increasing (linear) }\end{array}$ & & $\begin{array}{l}0-1,000 \mathrm{~m} \text { equal to } 0,1,000-3,000 \mathrm{~m} \text { between } 0-1 \text {, more than } 3,000 \\
\mathrm{~m} \text { equal to } 1\end{array}$ \\
\hline Distance from railway & $\begin{array}{c}\text { Monotonically } \\
\text { increasing (linear) }\end{array}$ & & $\begin{array}{c}0-2,000 \mathrm{~m} \text { equal to } 0,2,000-3,000 \mathrm{~m} \text { between } 0-1 \text {, more than } 3,000 \\
\text { m equal to } 1\end{array}$ \\
\hline
\end{tabular}

of factor i, respectively, and $\mathrm{N}$ indicates the total number of factor criteria. In order to consider constraints based on Boolean logic, constraints with the value of 0 should be multiplied by suitability as calculated from the factors. Equation (15) notes the mathematical form:

$$
S_{c}=\sum_{j=1}^{K} b_{j}
$$

...where $S_{c}$ stands for total suitability index value (0) and $\mathrm{K}$ and $b_{j}$ show total number of constraints and suitability index value for each constraint (0), respectively [41, 62].

Subsequently, in order to compute the final suitability index $S_{t}$, integrating total factor $\left(S_{f}\right)$ and total constrain suitability $\left(S_{c}\right)$ index via equation (16) was performed.

$$
S_{t}=S_{f} \times S_{c}
$$




\section{Results and Discussion}

As mentioned previously, according to literature review and identification of the study area, indices and criteria affecting municipal waste landfill sites were detected, wisely. Therefore, the ANP model structure was later designed to determine the weights of indices and criteria after reviewing relevant experts' opinions in the form of questionnaires. As shown in Fig. 3, the important criteria were classified into two categories: ecological and socio-economic.

The final weight of the indices and criteria were determined by implementing the above model. As shown in Table 3, the economic-social criteria with the final weight of 0.302168 compared with the ecological criteria with the final weight of 0.151083 played a more important role in determining suitable landfill sites in the process of evaluating the studied land area. This is despite the fact that indices, including distance from roads, distance from urban-constructed areas, and soil represent the most importance compared with other indices in the above study process, respectively, with importance coefficients of $0.080466,0.074147$, and 0.062027 .

In the study, distance from roads is considered a significant economic criterion in landfill siting. A primary buffer distance of $500 \mathrm{~m}$ is considered, while authors in [63] did the same because of optical intrusion, impacts on tourist attraction, transportation, cost-benefit investigation, and an urban area's future development.

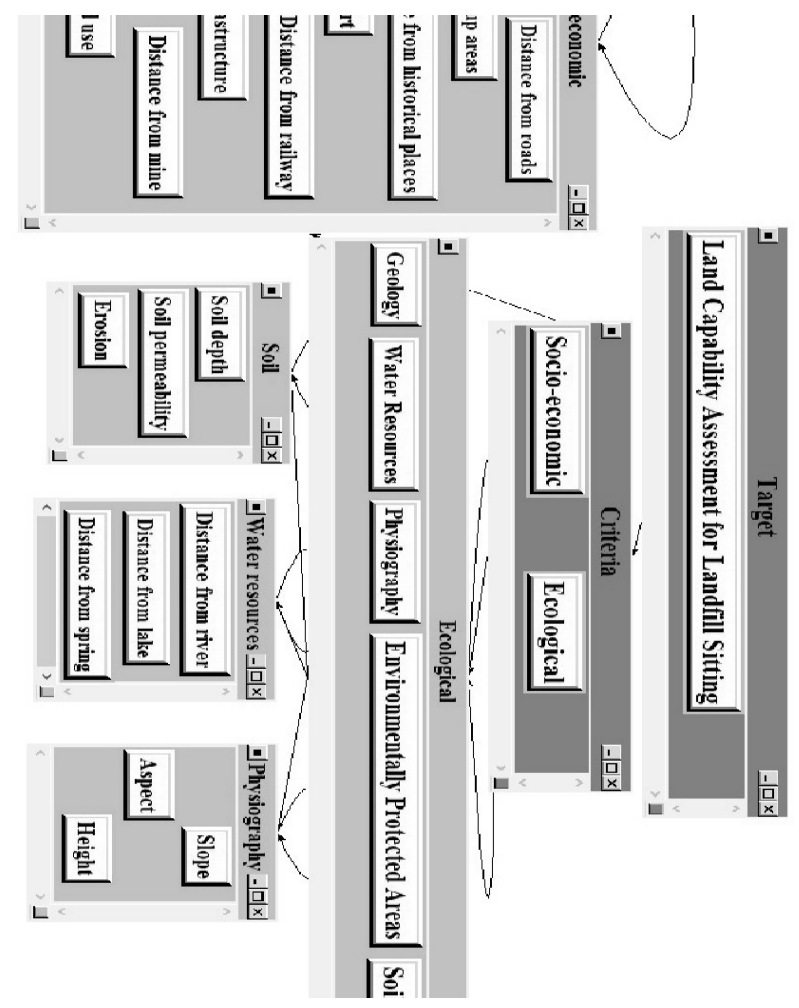

Fig. 3. ANP structure of land capability assessment for landfill site selection.
According to the environmental consideration of Iran's Department of the Environment, landfills cannot be located within $3000 \mathrm{~m}$ of a residential area. This study applied the mentioned buffer distance as well as [10] to support the reasons suggested by [63] because of crucial issues such as land value decline, health concerns, and optical and odour intrusion. Moreover, the importance of soil factor is directly because of the contamination risk of soil and groundwater by leachate. Although in the study area the water table is extremely low due to drought and overdraft, especially in recent years, soil pollution is still a major concern. Therefore, it is an undeniably important reason that the present study emphasized.

After determining the weights and the required thematic layer preparation, the WLC process was carried out and the final map generated (Fig. 4) to show HasanAbad land capability for an MSW landfill siting.

In order to generate a land capability map of HasanAbad according to the WLC method for landfill siting, first and foremost the index of $\mathrm{S}_{\mathrm{f}}$ (suitability of factor layers with the value of $0-1$ ) was specified by multiplying weights in the respective layers and adding them together. Moreover, the final suitability index for the HassanAbad (MSW) landfill was created by multiplying $\mathrm{S}_{\mathrm{f}}$ in $\mathrm{S}_{\mathrm{c}}$ (layers of constraints with the value of 0 ). Afterward, the reclassification operation was done according to Table 4. In other words, the land capability map can be classified based on the final value of each pixel $[41,56]$.

\section{MSW Landfill Siting Using WLC}

The interpretation of the final capability map shows that there are four categories of land capability in HasanAbad. As represented in Fig. 5, 82\% of the study area has no capability for an MSW landfill siting due to several ecological reasons, such as physiography (height, aspect, and slope) and erosion, as well as socioeconomic reasons like suitable distance from residential areas, historical places, faults and an airport. Statistics show that only $12 \%$ and $0.5 \%$ of Hasan-Abad have low and moderate capabilities, respectively. As can be seen, only $1 \%$ of this city falls under the high-capability class, while the extreme-capability class is found in no parts of the area.

It is important to consider that all of the polygons with suitable capability will not be planned for landfill siting. It is undeniably essential to prioritize them based on high suitability to reach the users' objective in landfill implementation procedure to consider the prerequisites of development. However, the final capability map represents a homogenous plan in term of capability.

In order to interpret the capability map of HasanAbad as driven by the WLC method, we performed intensive field studies and observations. The results of our field investigations completely justified the map. To explain more, as the capability map shows, the central part of Hasan-Abad has no capability for landfill siting, and fieldwork proved that the concentration of residential and built-up areas in this part diminishes as you go from the central parts to the margins. In addition, dry farming 
Table 3. Total weight of criteria and indices applying ANP model.

\begin{tabular}{|c|c|c|c|c|c|c|c|}
\hline $\begin{array}{c}\text { Criteria and } \\
\text { index }\end{array}$ & Weight & Criteria and index & Weight & $\begin{array}{c}\text { Criteria and } \\
\text { index }\end{array}$ & Weight & $\begin{array}{c}\text { Criteria and } \\
\text { index }\end{array}$ & Weight \\
\hline Ecological & 0.151083 & Aspect & 0.008524 & Soil Depth & 0.006728 & Road & 0.080466 \\
\hline Geology & 0.018822 & Slope & 0.001282 & Fault & 0.034217 & Mine & 0.025065 \\
\hline Water resources & 0.018965 & Height & 0.002699 & $\begin{array}{c}\text { Socio- } \\
\text { economic }\end{array}$ & 0.302168 & Infrastructure & 0.019216 \\
\hline River & 0.011886 & $\begin{array}{c}\text { Environmentally } \\
\text { protected areas }\end{array}$ & 0.004547 & $\begin{array}{c}\text { Built-up } \\
\text { area }\end{array}$ & 0.074147 & Railway & 0.007985 \\
\hline Spring & 0.005304 & Soil & 0.062027 & $\begin{array}{c}\text { Historical } \\
\text { sites }\end{array}$ & 0.018095 & & \\
\hline Lake & 0.001775 & Erosion & 0.039083 & Land use & 0.034930 & & \\
\hline Physiography & 0.012505 & Soil permeability & 0.016216 & Airport & 0.042264 & & \\
\hline
\end{tabular}

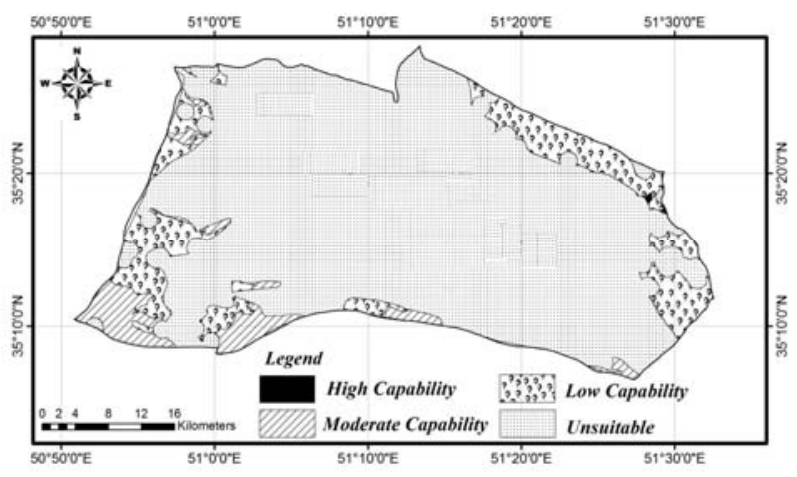

Fig. 4. Land capability map of Hasan-Abad according to WLC method for MSW landfill siting.

agricultural lands are located in the margins. Those that had been under dry farming before and now have the label of abundant considered as low capability class in the Hasan-Abad land capability map. Moreover, the moderate and high capability class in the map represent areas that faced land use changes from dryland farming to semi bare and completely bare over the years, respectively.

In addition, it should be mentioned that the results of the existing study support the investigations reported in [64] and [65]. They applied an analysis network process model and pointed out that it is one of the most appropriate

Table 4. Classification of Hasan-Abad land capability map for MSW landfill siting using WLC method.

\begin{tabular}{|c|c|c|}
\hline $\begin{array}{c}\text { Class } \\
\text { number }\end{array}$ & Land capability & $\begin{array}{c}\text { Final value of each } \\
\text { pixel }\end{array}$ \\
\hline 1 & Extreme capability & $0.8-1$ \\
\hline 2 & High capability & $0.6-0.8$ \\
\hline 3 & Moderate capability & $0.4-0.6$ \\
\hline 4 & Low capability & $0.2-0.4$ \\
\hline 5 & No capability & $0-0.2$ \\
\hline
\end{tabular}

techniques for resolving complicated issues. They noted that due to its flexibility, ANP can determine the relative importance of weights of criteria systematically, and a network relationship of a set of them that supports the decision-making process. Moreover, they reported that the integration of ANP and GIS through the MCDM method can provide more reliable results. Furthermore, authors in [66] proved that the multi-criteria decision-making technique that has been performed in the present study is highly capable of integrating the qualitative important criteria into numerical data and provides the possibility of decision-making regarding the mathematical computation, which is exactly the point that was emphasised in [67]. They mentioned that multi-criteria decision-making is an adequate method in site selection due to drawing the group of expert opinions to prioritize alternatives, indices, and criteria applying fuzzing techniques and the ANP model. To explain more about the use of fuzzy logic in this study, it is crucial to mention that applying certain logic and numbers in the quantifying indices procedure does not seem logical due to the very gradual changes in indices in the ecosystem. Therefore, the most reliable way to quantify qualitative indices is by applying fuzzy logic,

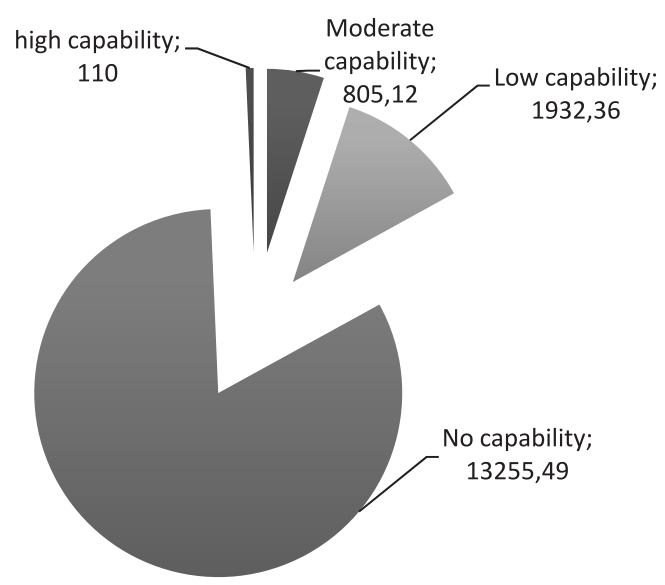

Fig. 5. Area of capability classes in Hassan-Abad (ha). 
Table 5. Comparison between MSW landfill siting studies based on the consideration of significant criteria.

\begin{tabular}{|c|c|c|c|c|c|c|c|c|c|c|c|c|c|c|c|c|c|c|c|}
\hline References & \multicolumn{19}{|c|}{ Criteria } \\
\hline & 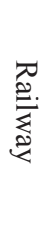 & 丞 & 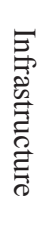 & 客 & 롤 & 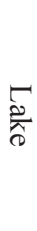 & 중. & 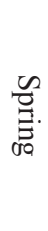 & 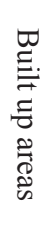 & 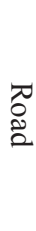 & $\begin{array}{l}\Gamma \\
\text { है } \\
\text { है } \\
\text { है } \\
\text { के }\end{array}$ & 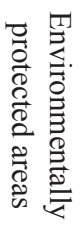 & 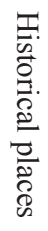 & $\begin{array}{l}\stackrel{\Omega}{0} \\
\stackrel{0}{\circ} \\
\stackrel{0}{g a}\end{array}$ & 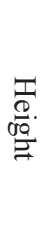 & 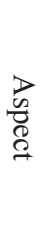 & $\frac{\Omega}{0}$ & 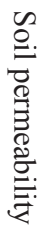 & $\begin{array}{l}\frac{T}{0} \\
0 \\
0 \\
0 \\
0\end{array}$ \\
\hline [10] & & * & & & $*$ & & $*$ & * & $*$ & * & $*$ & * & * & & & & $*$ & $*$ & \\
\hline [26] & & & & & & * & $*$ & $*$ & $*$ & * & & & & $*$ & $*$ & $*$ & $*$ & & \\
\hline [32] & $*$ & & & & & & & & $*$ & * & * & & * & & & & $*$ & & * \\
\hline [39] & $*$ & & * & & & & $*$ & & $*$ & * & $*$ & & $*$ & & $*$ & & $*$ & * & \\
\hline [73] & & & & & & & $*$ & & $*$ & * & $*$ & & & $*$ & $*$ & & $*$ & & $*$ \\
\hline $\begin{array}{l}\text { The present } \\
\text { study }\end{array}$ & $*$ & $*$ & $*$ & $*$ & $*$ & $*$ & $*$ & $*$ & $*$ & $*$ & $*$ & $*$ & $*$ & $*$ & $*$ & $*$ & $*$ & $*$ & $*$ \\
\hline
\end{tabular}

which is highly capable for presenting final results that resemble real conditions well [68-72].

Also, as mentioned previously, the literature review helped to identify important parameters to assess the land capability for siting an MSW landfill in Hasan-Abad. For instance, studies showed that the soil parameter is a crucial factor in identifying suitable landfill sites because of its significant role in controlling landfill leachate, which is undeniably one of the most important landfill impacts [63]. Therefore, three parameters, including soil depth, soil permeability power, and erosion were considered in this study. However, the literature review shows that the soil parameter was not included in the MSW landfill site selection procedure in some studies [11, 17, 32]. In addition, the other substantial factor is an aspect that is categorized under the name of physiography in this study and indicates wind direction. On the one hand, the significance of this criterion is because it can easily distribute landfill-emanated odours. On the other hand, decomposing degradable substances in a landfill generates methane gas and it is a major type of air pollution [26]. So environment-wise, it is undeniably important to take this into consideration, although authors in [10] and [12] did not consider aspects in the landfill site selection process. To sum up, Table 5 represents a comparison between the consideration of important criteria in MSW landfill siting process by the present and some other studies.

Since landfill site selection is a complex procedure, it is essential to take a wide range of factors into consideration in order to minimize further negative impacts on the ecosystem. This is a reason to focus on covering all the effective criteria based on Hasan Abad conditions in the landfill site selection process, although there is a possibility to ignore one or more items in these kinds of studies according to the study area features. However, some criteria, like soil, aspect, geology, and erosion, are mostly common and fixed and are to be considered.

\section{Conclusions}

Since sustainable urban development emphasizes improving the quality of urban environments as a dynamic system, the optimal management of MSW is undoubtedly important, especially from environmental and health points of view due to the high volume of their daily production in all countries. Although there are several strategies in municipality solid waste management, the sanitary landfill is still the most common in many countries - especially developing ones such as Iran. Identifying suitable landfill sites needs to consider many factors according to the characteristics of the study area. Hence, after conducting field studies (to identify study area) and reviewing the literature, 20 important criteria are categorized into two classes: ecological and socioeconomic.

In the present study, due to the GIS ability in data analysis, appropriate and effective database establishment, and the flexibility to apply such models as WLC, the combination of GIS, fuzzy logic (for standardization of factor maps), Boolean logic (for standardization of constrain maps), and multi-criteria assessment methods (MCDM) (to investigate the capability of Hassan-Abad lands) was used for MSW landfill siting. After applying weights driven by the network analysis model (ANP) to the indices and criteria, the integration of factor and constraint maps carried out, a land suitability map of the study area was prepared using the WLC approach. It should be noted that the results of this study only represent the appropriateness and inappropriateness of Hassan Abad lands for MSW landfill siting, and it is not a final decision by itself. Thus, other considerations such as public acceptance, land ownership, economic development studies, landfill environmental impact assessments, and more field studies should be considered in the final decision. 


\section{Acknowledgements}

The authors would like to acknowledge Dr. Hamide Aliani for her scientific assistance.

\section{References}

1. CHUNPING L., GUOXUE L., YIMING L., YANFU L., JIAN H. Environmental monitoring and fuzzy synthetic evaluation of municipal solid. waste transfer stations in Beijing in 2001-2006. Journal of environmental sciences, 20, 998, 2008.

2. GUPTA N., YADAV K.K., KUMAR V. A review on current status of municipal solid waste management in India. Journal of environmental sciences, 37, 206, 2015.

3. LAI K., LIM S., THE P., YEAP K. Characterizing a Novel Food Waste Recovery Process Using an Electrostatic Separator. Polish Journal of Environmental Studies, 25 (5), 2227, 2016.

4. BRONJA H., BRONJA H. A multi-criteria approach to selecting a landfill site with the aim of protecting the environment. Polish Journal of Environmental Studies, 23 (5), 1499, 2014.

5. KULCYZCKA J., LELEK L., LEWANDOWSKA A., ZAREBSKA J. Life Cycle Assessment of Municipal Solid Waste Management - Comparison of Results Using Different LCA Models. Polish Journal of Environmental Studies, 24, (1), 125, 2015.

6. SAHERI S., AGHAJANI MIR M., BASRI N.E.A., MAHMOOD N.Z.B., BEGUM R.A. Life Cycle Assessment for solid waste disposal options in Malaysia. Polish Journal of Environmental Studies, 21 (5), 1377, 2012.

7. ABDOLI M.A. Recycling of Municipal Solid Wastes. Publisher: Tehran University, Iran, 101, 2005. [In Persian]

8. MALLAK K.SH., BAKRI ISHAK M., KASIM M.R.M., ABU SAMAH M.A. Assessing The Effectiveness of Waste Minimization Methods in Solid Waste Reduction at the Source by Manufacturing Firms in Malaysia. Polish Journal of Environmental Studies, 24 (5), 2063, 2015.

9. MOEINADDINI M., KHORASANI N., DARVISHSEFAT A.A., ZIENALYAN M. Siting MSW landfill using weighted linear combination and analytical hierarchy process (AHP) methodology in GIS environment (case study: Karaj). Waste Management, 30, 912, 2010.

10. KARIMZADEH- MOTLAGH Z., SAYADI M.H. Siting MSW landfills using MCE methodology in GIS environment (case study: Birjand plain, Iran). Waste Management, 46, 322, 2015.

11. KONTOS T.D., KOMILIS D.P., HALVADAKIS C.P. Siting MSW landfills with a spatial multiple criteria analysis methodology. Waste Management, 25, 818, 2005.

12. JAMSHIDI A., KAZEMI JAHANDIZI E., MOSHTAGHIE M., MONAVARI S.M., TAJZIEHCHI S., HASHEMI A., JAMSHIDI M., ALLAHGHOLI L. Landfill Site Selection: a Basis Toward Achieving Sustainable Waste Management. Polish Journal of environmental Studies, 24 (3), 1021, 2015.

13. KIM K.R., OWENS, G. Potential for enhanced phytoremediation of landfills using bio-solids: a review. Journal of Environmental Management, 91 (4), 791, 2010.

14. MAHMOOD KH., BATOOL S.A., CHAUDHRY M.N., DAUD A. Evaluating municipal solid waste dumps using geographic information system. Polish Journal of Environmental Studies, 24 (2), 879, 2015.
15. MUTLUTURK M., KARAGUZEL R. The landfill area quality (LAQ) classification approach and its application in Isparta, Turkey. Environmental and Engineering Geoscience, 13, 229, 2007.

16. SENER B., LUTFI SUZEN M., DOYURAN V. Landfill site selection by using geographic information systems. Environmental Geology, 49, 376, 2006.

17. SENER S., SENER E., NAS B., KARAGUZEL R. Combining AHP with GIS for landfill site selection: A case study in the Lake Beysehir catchment area (Konya, Turkey). Waste Management, 30, 2037, 2010.

18. SUMATHI V.R., NATESAN U., SARKAR C. GIS-based approach for optimized siting of municipal solid waste landfill. Waste Management, 28, 2146, 2008.

19. BALL J.M., ROAD L. Landfill site selection. Tenth International Waste Management and landfill symposiums, 1250, 2005

20. CHANG N., PARVATHINATHANB G., BREDEN J.B. Combining GIS with fuzzy multicriteria decision making for landfill siting in a fast-growing urban region. Journal of Environmental Management, 87, 139, 2008.

21. KONTOS T.D., KOMILIS D.P., HALVADAKIS C.P. Siting MSW landfills on Lesvos Island with a GIS based methodology. Waste Management \& Research, 21, 262, 2003.

22. DELGAdO O.B., MENDOZA M., GRANAdOS E.L., GENELETTI D. Analysis of land suitability for the siting of inter-municipal landfills in the Cuitzeo Lake Basin, Mexico. Waste Management, 28, 1137, 2008.

23. EASTMAN R.J. IDRISI 32, Release 2. Tutorial. Clark University, USA. 280, 2001.

24. CHEN Y., YU J., KHAN S. Spatial sensitivity analysis of multi-criteria weights in GIS-based land suitability evaluation. Environmental Modeling \& Software, 25 (12), 1582, 2010.

25. ESKANDARI M., HOMAEE M., MAHMODI S. An integrated multi criteria approach for landfill siting in a conflicting environmental, economical and socio-cultural area. Waste Management, 32, 1528, 2012.

26. GBANIE S.P., TENGBE P.B., MOMOH J.S., MEDO J., KABBA V.T.S. Modelling landfill location using Geographic Information System (GIS) and Multi-Criteria Decision Analysis (MCDA): Case study Bo, Southern Sierra Leon. Applied Geography, 36, 3, 2013.

27. AJIT P., SINGH A., VIDYARTHI K. Optimal allocation of landfill disposal site: a fuzzy multi-criteria approach, Iran. Journal of Environmental Health science \& Engineering, 5 (1), 25, 2008.

28. AKBARI V., RAJABI M.A., CHAVOSHI S.H., SHAMS R. Landfill site selection by combining GIS and Fuzzy multi-criteria decision analysis, case study: Bandar Abbas, Iran. World Applied Sciences Journal, 3, 39, 2008.

29. ALlEN A., BRITO G., CAETANO P., COSTA C., CUMMINS V., DONELLY J., FERNADES C., KUKUPAS S., O'DONELL V., ROBALO C., VENDAS D. Procedure for the location of landfill sites using a GIS model. In $9^{\text {th }}$ Congress of the International Association of Engineering Geology and the Environment, Durban, South Africa, 100, 2002.

30. GUIQIN W., LI Q., GUOXUE L., LIJUN C. Landfill site selection using spatial information Technologies and AHP: a case study in Beijing, China. Journal of Environmental Management, 90, 2414, 2009.

31. JAVAHERI H., NASRABADI T., JAFARIAN M.H., ROWSHAN G.R., KHOSHNAM H. Site selection of municipal solid waste landfills using analytical hierarchy 
processes method in a geographical information technology environment in Giroft, Iran. Journal of Environmental Health Science Engineering, 3, 177, 2006.

32. NAS B., CAY T., ISCAN F., BERKTAY A. Selection of MSW landfill site for Konya, Turkey using GIS and multi-criteria evaluation. Environmental Monitoring \& Assessment, 160, 491, 2010.

33. PADMAJA V., ASADF S.S., ANJI M.R. Solid waste disposal site selection using analytical hierarchy process and GIS. Pollution Research, 25 (1), 73, 2006.

34. THEMISTOKLIS D.K., DIMITROIS P.K. CONSTANTINOS P.H. Siting MSW landfills with a spatial multiple criteria analysis methodology. Waste management, 25, 818, 2005.

35. WANG G., QIN L., LI G., CHEN L. Landfill site selection using spatial information technologies and AHP: a case study in Beijing, China. Journal of Environmental Management, 90, 2414, 2009.

36. YAHAYA S., ILORI C., WHANDA S.J., EDICHA J. Landfill site selection for Municipal Solid Waste Using Geographic Information System and Multi-criteria Evaluation. American Journal of Scientific Research, 10, 34, 2010.

37. AL-HANBALI A., ALSAAIDEH B., KONDOH A.Using GIS-Based Weighted Linear Combination Analysis and Remote Sensing Techniques to Select Optimum Solid Waste Disposal Sites within Mafraq City, Jordan. Journal of Geographic Information System, 3, 267, 2011.

38. ISALOU A.A., ZAMANI V., SHAHMORADI B., ALIZADEH H. Landfill site selection using integrated fuzzy logic and analytic network process (F-ANP). Environmental Earth Science, 68, 1745, 2013.

39. CHABUK A., AL-ANSARI N., HUSSAIN M.H., KNUTSSON S., PUSCH R. Landfill site selection using geographic imformation system and analytical hierarchy process: A case study Al-Hillah Qadhaa, Babylon, Iraq. Waste management and research, 34 (5), 427, 2016.

40. HASAN-ABAD Municipality. Available online: http:// hassanabadcity.ir/2016-06-01-07-34-22/2016-06-01-07-3455/2016-06-01-07-35-37. (Accessed on 12 Aguste 2016).

41. ALIANI H., BABAIE KAFAKI S., SAFFARI A. Determining an appropriate method for the purpose of land allocation for ecotourism development (case study: Taleghan County, Iran. Environmental Monitoring \& Assessment. Doi:10.1007/s10661-016-5651-2, 2016.

42. OZKAN A., BANAR M. Refuse derive fuel (RDF) utilization in cement industry by using analytical network process (ANP). Chemical Engineering Transactions, 21, 747, 2010.

43. YANG CH.L., YUAN B.J.C., HUANG CH.Y. Key Determinant Derivations for Information Technology Disaster Recovery Site Selection by the Multi-Criterion Decision Making Method. Sustainability , 7, 6149, 2015.

44. BARZEKAR G., AZIZ A., MARIAPAN M., ISMAIL M. H., HOSSENI S. M. Delphi technique for generating criteria and indicators in monitoring ecotourism sustainability in Northern forests of Iran: case study on Dohezar and Sehezar Watersheds. Folia Forestalia Polonica Series, 53 (2), 130, 2011.

45. GHODDOUSI J. Application of MCDM techniques in HSE and Environment management. Lecture note. IAU. Science and Research Branch, Tehran. College of Environment and Energy. 45, 2014. [In Persian]

46. SAATY T.L., VARGAS L.G. Decision Making with the Analytic Network Process, Springer, Pittsburgh, USA, 108, 2006.
47. WICHER P., ZAPLETAL F., LENORT R., STAS D. Measuring The Metallurgical Supply Chain Resilience Using Fuzzy Analytic Network Process. Journal Metalurgija, 55 (4), 783, 2016.

48. MCBRATNEY A.B., ODEH O.A. Application of fuzzy sets in soil science: fuzzy logic, fuzzy measurements and fuzzy decisions. Geoderma, 77, 85, 1997.

49. ZHANG Y. The Application of Fuzzy-ANP and SD Software in the Assessment of Organic Chemistry Teachers' Bilingual Teaching Competency. Advance Journal of Food Science and Technology, 5 (6), 707, 2013.

50. BORAN S., GOZTEPE K. Development of a fuzzy decision support system for commodity acquisition using fuzzy analytic network process. Expert Systems with Applications, 37, 1939, 2010.

51. GOZTEPE K. A study on OS selection using ANP based Integral in Terms of cyber Threats. International Journal of Information Security Science, 1 (2), 67, 2012.

52. SAATY T.L. Decision Making for Leaders: The Analytic Hierarchy Process for Decisions in a Complex World $\left(3^{\text {rd }}\right.$ Ed.). Pittsburgh, PA: RWS Publications, 84, 1996.

53. SAATY T.L. The Analytic Hierarchy Process, McGrawHill, Inc., New York, USA, 22, 1980.

54. DAGDEVIREN M., YUKSEL I. A fuzzy analytic process (ANP) model for measurement of the sectoral competition level (SCL). Expert Systems with Applications, 37, 1005, 2010.

55. KAHRAMAN C., ERTAY T., BUYUKOZKAN G. A fuzzy optimization model for QFD planning process using analytic network approach. European Journal of Operational Research, 171 (2), 390, 2006.

56. DASHTI S., MONAVARI S.M., HOSEINI S.M., RIAZI B., MOMENI M. Application of GIS, AHP, Fuzzy and WLC in Island Ecotourism Development (Case study of Qeshm Island, Iran). Life Science Journal, 10 (1), 1274 , 2013.

57. MAHINI A.S., GHOLAMALIFARD M. Siting MSW landfills with a weighted linear combination methodology in a GIS environment. International Journal of Environmental Science Technology, 3 (4), 435, 2006.

58. MAVI K.R., KAZEMI S., NAJAFABADI F.A., MOUSAABADI H.B. Identification and Assessment of Logistical Factors to Evaluate a Green Supplier Using the Fuzzy Logic DEMATEL Method. Polish Journal of Environmental Studies, 22 (2), 445, 2013.

59. SHAHABI H., AHMAD A.B., AHMAD B.B., AMIRI M.J.T., KEIHANFARD S., EBRAHIMI S. Assessment of WLC and Fuzzy Logic Methods for Site Selection of Water Reservoirs in Malaysia. Polish Journal of Environmental Studies, 25 (3), 1223, 2016.

60. EASTMAN R.J. IDRISI Andes guide to GIS and image processing. Clark University. 89, 2006.

61. AFZALI A., SAMANI J.M.V., RASHID M. Municipal Landfill Site Selection for Isfahan city by use of Fuzzy Logic and AHP. Iran Journal of Environmental Health Science \& Engineering, 8, 273, 2011.

62. GEMITZI A., TSIHRINTZIS V.A., VOUDRIAS E., PETALAS C., STRAVODIMOS G. Combining geographic information system, multicriteria evaluation techniques and fuzzy logic in siting MSW landfills. Environmental Geology, 51, 797, 2007.

63. DEMESOUKA O.E., VAVATSIKOS A.P., ANAGNOSTOPOULOS K.P. Suitability analysis for siting MSW landfills and its multi-criteria spatial decision support system: Method, implementation and case study. Waste Management, 33, 1190, 2013. 
64. BABALOLA A., BUSU I. Selection of landfill sites for solid waste treatment in Damaturu Town-using GIS techniques. Journal of Environmental Protection, 2, 1, 2011.

65. KHAN SH., FAISAL M.N. An analytic network process model for municipal solid waste disposal options. Waste Management, 28, 1500, 2008.

66. KHORRAM A., YOUSEFI M., ALAVI S.A., FARSI J. Convenient Landfill Site Selection by Using Fuzzy Logic and Geographic Information Systems: A Case Study in Bardaskan, East of Iran. Health Scope, 4 (1), e19383, 2015.

67. CHYU C.C., FANG Y.C. A Hybrid Fuzzy Analytic Network Process Approach to the new product development selection problem.Mathematical Problems in Engineering, 2014, Hindavi.com. available on: http:// dx.doi.org/10.1155/2014/485016.

68. DAVAMI A.H., MOHARAMNEJAD N., MONAVARI S.M., SHARIAT M. An urban solid waste landfill site evaluation process incorporating GIS in local scale environment: a case of Ahvaz city, Iran. International Journal of Environmental Research, 8 (4), 1011, 2014.

69. ERKUT E., MORAN S.R. Locating obnoxious facilities in the public sector: An application of the hierarchy process to municipal landfill siting decisions. Socio-Economic Planning Sciences, 25 (2), 89, 1991.

70. GORSEVSKI P.V., DONEVSKA K.R., MITROVSKI C.D., FRIZADO J.P. Integrating multi-criteria evaluation techniques with geographic information systems for landfill site selection: a case study using ordered weighted average. Waste Management, 32, 287, 2012.

71. RAHMAN M.M., SULTANA K.R., HOQUE M.A. Suitable sites for urban solid waste disposal using GIS approach in Khulna city, Bangladesh. Proceedings of Pakistan Academy of sciences, 45 (1), 11, 2008.

72. SENER S., SENER E., KARAGUZEL R. Solid waste disposal site selection with GIS and AHP methodology: a case study in Senirkent-Uluborlu (Isparta) Basin, Turkey. Environmental Monitoring \& Assessment, 173, 533, 2011.

73. TORABI K.M., BABAZADEH R., MOHAMMADI S.D., ZARESEFAT M. Landfill site selection using combination of GIS and Fuzzy AHP, a case study: Iranshah, Iran. Waste management and research, 34 (5), 438, 2016. 